\title{
Assessing the effects of local contexts on the mobility choices of university students in Campania region in Italy
}

\author{
Francesco Santelli ${ }^{*}{ }^{*}$, Giancarlo Ragozini ${ }^{1}$ and Maria Prosperina Vitale ${ }^{2}$
}

\author{
${ }^{*}$ Correspondence: \\ francesco.santelli@unina.it \\ ${ }^{1}$ Department of Political \\ Science, University of Naples \\ Federico II, via Rodinó 22A \\ 80138 Naples, Italy \\ Full list of author information \\ is available at the end of the \\ article
}

\begin{abstract}
The mobility of university students in Italy has been framed as a phenomenon linked to so-called intellectual migrations and as a subset of the historical and consolidated internal migration path explained in terms of South-North trajectory. This study describes the most important mobility trajectories of students across macro-areas and disciplinary fields, and then evaluates, using a multilevel logistic regression model, the factors that encouraged student cohort, who were enrolled in a degree program in the academic years 2014-2015, to move elsewhere from the Campania region. Beyond fixed and interaction effects related to the students' personal characteristics, the model included possible random effects linked to the high schools attended by the students to capture the possible influence of the local context on migration choices.
\end{abstract}

Keywords: Student mobility, Multilevel model, South-North trajectory, Disciplinary field

\section{Introduction}

The mobility of university students in Italy has been framed as a phenomenon linked to intellectual migration and as a particular subset of the historical and consolidated internal migration path in Italy, which shows the well-established South-North trajectory. The social, cultural, and economic impoverishment of the Southern regions resulting from the mobility, in the form of outflow of university students, has been widely discussed in literature (Nifo \& Vecchione, 2014). It is, therefore, important to deepen the discourse by shedding light on to the possible factors that explain such mobility, as analyzed during the transition from high school to the first enrollment. We are aware that other crucial steps in the careers of university students take place after the first year of the bachelor's degree program and during the transition from the bachelor's to the master's degree programs. The focus of this contribution is on "first level mobility", and we consider only the choices of the freshmen in the student cohort in our analysis. Several related studies have tried to address this issue considering individual micro-data (Bacci \& Bertaccini, 2020; Columbu et al., 2020; D’Agostino et al., 2019; Enea, 2018; Genova et al., 2019) and a macro-level point of view (Columbu et al., 2020; Santelli et al., 2019).

(c) The Author(s) 2022. Open Access This article is licensed under a Creative Commons Attribution 4.0 International License, which permits use, sharing, adaptation, distribution and reproduction in any medium or format, as long as you give appropriate credit to the original author(s) and the source, provide a link to the Creative Commons licence, and indicate if changes were made. The images or other third party material in this article are included in the article's Creative Commons licence, unless indicated otherwise in a credit line to the material. If material is not included in the article's Creative Commons licence and your intended use is not permitted by statutory regulation or exceeds the permitted use, you will need to obtain permission directly from the copyright holder. To view a copy of this licence, visit http:// creativecommons.org/licenses/by/4.0/. 
Few authors tried to establish the effects of a particular migration chains and looked at the effects of the local contexts on the determination of the migration flows to the universities in the North that attract students from the South, also from a social network analysis perspective (Genova et al., 2019).

The present contribution assesses if the local geographical contexts within the Campania region in southwestern Italy (Santelli et al., 2019; Santelli et al., forthcoming) exert some effects on the migration choices, by considering data from our student cohort and controlling for individual characteristics. To measure these effects, the specific high school attended by the students was used as a proxy for the local context. The main assumption that we investigated is that students attending the same high school and who have similar sociocultural contexts have similar experiences in terms of the university orientation process before they enroll in a certain bachelor degree program, and thus, have similar perspectives on the university that they should enroll in. Moreover, students are attracted to geographic areas and universities with a high reputation, and sometimes, enrollment in a university located outside of the region furthers social stratification.

Within this scenario, we consider mobility flows of a cohort of students who reside in the Campania region who are enrolled as freshmen in a bachelor's degree program, in or outside the region, in the academic years 2014-2015. Their microdata were gathered from the MOBYSU.IT database ${ }^{1}$ maintained by the Italian Ministry of University and Research. First, we explore the overall university mobility choices of the cohort under analysis, especially why they moved out of the Campania region to their current destination. Particular attention is devoted to: (1) the students' South-North mobility trajectory, from a macroarea perspective; (2) the enrollment in specific disciplinary fields; and (3) the mobility trajectories of students residing in a specific region of Southern Italy. Second, a multilevel logistic regression model (Snijders \& Bosker, 2011) is used to assess the effect of the local geographic contexts on the probability of students moving outside the region of residence. This model was chosen to take into account the hierarchical structure inherent university students' mobility in line with related literature. The model includes covariates of the individual characteristics and grouping variables related to high schools. Using this model, we analyze the propensity of the students to move or not from the Campania region. For this purpose, we classify the students into the stayers category, who enrolled in a university in the region, and into the movers category, who enrolled in a university located outside the Campania region.

The remainder of the paper is structured as follows. A brief literature review is presented in "Theoretical framework" section. The micro-data used at student level used to describe the overall mobility trajectories of the 2014 student cohort are discussed in "The data" section. The model used to analyze the determinants of the probability to move is described in "Modeling the probability of being a mover" section. The main analysis results are reported in "Main results" section with a discussion of the role played by some high schools located in particular geographic areas in student mobility choices. The concluding remarks are given in "Concluding remarks" section.

1 The microdata at the student level are available at the the National Students Registry (ASN) https://anagrafe.miur.it/ index.php only for the universities involved in the Italian Ministerial Grant PRIN 2017 CUP: B78D19000180001. 


\section{Theoretical framework}

Student mobility in higher education, involving students' flows to areas of the same country (Ciriaci, 2014) or to other countries (Fernex et al., 2017; Restaino et al., 2020), is a crucial phenomenon to study due to a plethora of factors related to: the role of the university reputation (Bacci \& Bertaccini, 2020) and perceived quality in students' geographic mobility choices (Impicciatore \& Tosi, 2019), the implications of such choices on the local labor market conditions and economic growth (Dotti et al., 2013), the search for better working conditions (Lombardi \& Ghellini, 2019) and quality of life, because such mobility generates disparities and increase the gap between the North and the South in Italy (D'Agostino et al., 2019). Indeed, the attractiveness of some geographic areas and universities (Columbu et al., 2020; Giambona et al., 2017) is yielding a decline in the human capital of a country in specific undeveloped areas that export young students (Nifo \& Vecchione, 2014). In addition, it seems that early student migration to the North to attend a university located there, together with a fast transition to the first job, improves both intergenerational social mobility and the probability of staying at the top of the occupational hierarchy (Impicciatore \& Panichella, 2019). This phenomenon, called brain drain and later described with the expression intellectual migration, is further investigated to discover economic, social, cultural, and institutional determinants of students' choices to migrate after high school to areas outside their region of residence to attend a bachelor's degree program, which defines a student mover's profile.

In Italy, recent studies have shown that the most relevant and growing student mobility flow is from the Southern to the Central-Northern regions (Columbu et al., 2020; D’Agostino et al., 2019; Enea, 2018; Genova et al., 2019; Pitzalis \& Porcu, 2015; Santelli et al., 2019). These studies focused mainly on the determinants of the probability of high school students moving to other locations to attend a bachelor's and/or a master's degree program.

In such studies, using microdata on students maintained by the National Students Registry (ASN) archive integrated with other official statistics and survey data, the factors that affect student mobility choices were investigated by considering the students' personal characteristics and indicators of the attractiveness of geographic areas and institutions. More specifically, D’Agostino and Ghellini (D’Agostino et al., 2019) examined the relative influence of individual and contextual factors (e.g., per capita gross income, employment rate, quality life index, and university quality indicator provided by Sole24Ore) on the determination of the propensity of university freshmen to migrate from southern to northern/central regions. Columbu et al. (Columbu et al., 2020) explored the determinants of university attractiveness for movers by considering individual characteristics of students provided by the ANS archive (gender, age upon enrollment, and high school final grade and type) with socioeconomic indicators of the provinces in which the universities are located (youth unemployment rates, gross value added, tertiary education supply, etc.) and other information concerning the reputation of universities, fields of study and degree programs (Almalaurea ${ }^{2}$ indicators).

\footnotetext{
${ }^{2}$ AlmaLaurea is a Inter-university Consortium established in 1994 and currently counts 78 Universities as members and represents about $90 \%$ of Italian graduates.The Consortium surveys the Profile and the Employment status of the graduates annually after 1, 3 and 5 years, and monitors the students' learning paths and analyses the graduates' features and performance at the university and in the job market.
} 
Student mobility flows have also been analyzed in particular geographic areas in South Italy, also in the Sicily and Campania regions. Genova et al. (Genova et al., 2019) described student mobility as a chain migration phenomenon, where students move to a particular destination to follow other students who have previously moved to the same place. Network analysis results have proven the existence of this migratory chain over time by showing a preferential network pattern in the increase of the number of movers from Sicily to the central and northern Italian universities, related to clusters of municipalities, where students live.

The migration from the Campania region (Santelli et al., 2019; Santelli et al., forthcoming) to the rest of Italy, compared with other southern regions, instead, has been shown to behave in a different manner with respect to student mobility dynamics. This geographic area presents a relevant attractive power that is in contrast to other Southern regions that are suffering from increasing student outflows. For this reason, the present study, after performing a exploratory analysis of the overall migration trajectories of the student cohort under analysis, investigates the factors that explain Campania students mobility choices using a confirmatory approach.

\section{The data}

The students' micro-data were gathered from the MOBYSU.IT database maintained by the Italian Ministry of University and Research. This database contains longitudinal data on university student careers and bachelor's and master's degree programs from 2008 to 2017, and data on students' socio-demographic characteristics and high school performance. These information are provided in an aggregated way in the open data by the ANS archive.

In this paper, we focus on micro-data of the cohort of freshmen enrolled in an Italian university in the academic years 2014-2015. A total of 228,722 students were identified. To obtain a homogeneous set of students consistent with our research goal, we filtered the data by removing students: (1) who were not Italian citizens; (2) who had attended, even partially, a university career abroad; (3) on whom the database did not report clear information on their region of birth; (4) who had taken other university degrees in previous years; and (5) who were enrolled in online degree programs of Telematic (online) universities.

After removing all these records from original data set (around the 5\%), a total of 217,571 students is considered. First, in the following subsection, we outline the main aspects of such cohort. Second, according to our aims, data of students resident in Campania region are extracted and analyzed in "Main results" section to study the determinants of probability to move from Campania region to other destinations to attend a university degree program.

\section{Overview on the mobility data and description of the student cohort South-North mobility trajectory of students at a glance}

Given the theoretical framework and the related literature described in "Theoretical framework" section, the South-North mobility trajectory in Italy can be seen as a phenomenon that is a result of historical dynamics and a mixture of individual choices based 
Table 1 Freshmen in 2014-2015 for macro-area of origin (rows) and destination (columns). Percentages are rows-relatives

\begin{tabular}{lllllll}
\hline & North-West & North-East & Center & South & Islands & Total \\
\hline North-West & $51476(93.3 \%)$ & $2779(5.0 \%)$ & $785(1.4 \%)$ & $101(0.2 \%)$ & $24(0 \%)$ & 55165 \\
North-East & $2273(5.8 \%)$ & $35684(91.7 \%)$ & $874(2.2 \%)$ & $90(0.2 \%)$ & $10(0 \%)$ & 38931 \\
Center & $1302(2.8 \%)$ & $1938(4.2 \%)$ & $41672(90.7 \%)$ & $1014(2.2 \%)$ & $10(0 \%)$ & 45936 \\
South & $3403(6.1 \%)$ & $2432(4.4 \%)$ & $6076(10.9 \%)$ & $43323(77.6 \%)$ & $580(1.0 \%)$ & 55814 \\
Islands & $2359(10.9 \%)$ & $1114(5.1 \%)$ & $1898(8.7 \%)$ & $230(1.1 \%)$ & $16124(74.2 \%)$ & 21725 \\
Total & 60813 & 43947 & 51305 & 44758 & 16748 & 217571 \\
\hline
\end{tabular}

on several aspects, such as personal decisions, environment factors, universities policies, and job opportunities. To analyze this phenomenon, for each Italian region, we consider

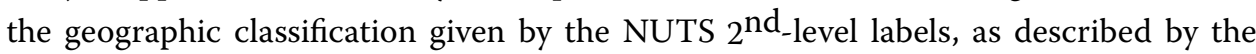
official EUROSTAT georeferences ${ }^{3}$ and widely used for official statistics and surveys.

Table 1 shows the number of freshmen enrolled in the universities in the five macroareas (in terms of the students origin, where they are resident, and destination, where they are enrolled). It shows that most of the students start university in the geographic area in which they live (i.e., the main diagonal in Table 1). The overall pattern shows that the North-West, North-East and Center are the areas that keep the greatest number of their students (with percentages of stayers ${ }^{4}$ ranging from $93.3 \%$ for the North-West to the $90.7 \%$ for the Center). For the South and the Islands, the percentages of stayers are $77.6 \%$ and $74.2 \%$. A total of 77,539 students live in the South and the Islands, representing the $33.8 \%$ of the student cohort under analysis. Notably, South and Islands have almost not exchanged students $(1.0 \%$ from the South to the Islands and $1.1 \%$ from the Islands to the South), unlike the North-West and the North-East (around 5\% between each other). More than 11,000 and 5000 students left the South and the Islands macroareas to study elsewhere. Students from the South are moving especially to the Center (10.9\%), while main destination from the Islands is the North-West (10.9\%). The NorthWest and the North-East exchange students between them (about 5000 students in total), and students from the Center move especially to the North ( $4.2 \%$ to the NorthEast and 2.8\% to the North-West).

Besides these kind of mobility patterns observed at the first enrollment (at the bachelor's level), the other mobility pattern was observed at the enrollment for the first year of the master's degree. To analyze it, we considered only the students in the 2014-2015 cohort who enroll in first year of the master's degree program (excluding those who dropped out or completed the bachelor's degree program but did not continue with master's studies).

A significant percentage of students in this cohort, $46.7 \%$, did not obtain a bachelor's degree program in the considered time window. Overall, $69.3 \%$ did not enroll for the

\footnotetext{
3 The map of the official classification of Italian regions in NUTS $2^{\text {nd }}$-level is available at: https://ec.europa.eu/euros tat/documents/345175/7451602/2021-NUTS-2-map-IT.pdf. It divides the 20 regions into 5 macro-areas: North-West (Piedmont, Aosta Valley, Liguria, Lombardy), North-East (Trentino- South Tyrol, Veneto, Friuli-Venezia Giulia, EmiliaRomagna), Center (Tuscany,Umbria, Marche, Lazio), South (Abruzzo, Molise, Campania, Apulia, Basilicata, Calabria) and Islands (Sicily, Sardinia).

${ }^{4}$ In this case, we paralleled the stayer and mover definitions at the regional level, as given in the Introduction, to the higher macro-area level.
} 


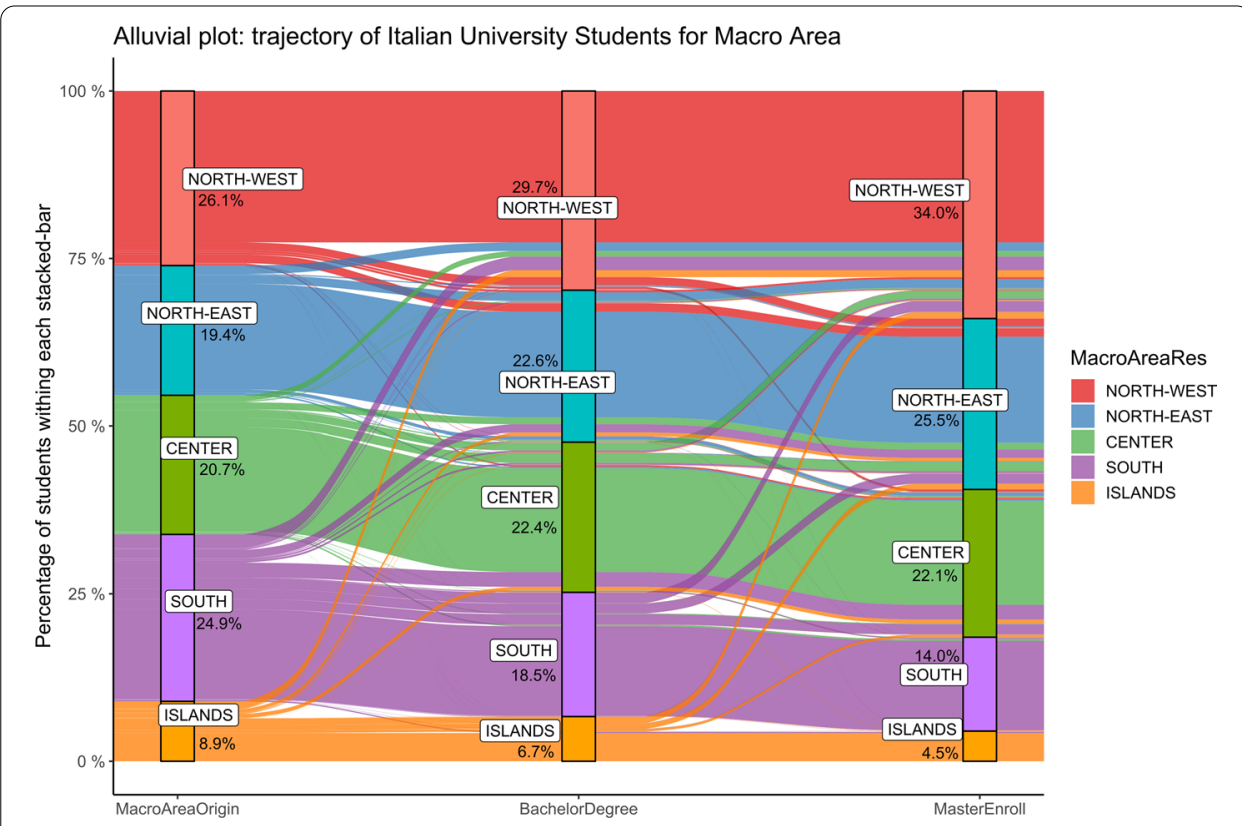

Fig. 1 Italian students'flows according to residence, bachelor and master degree territorial macro-areas

master's degree; and among those who that have earned a bachelor's degree program, only $57.6 \%$ pursued a master's degree program. For this additional mobility for master's degree enrollment, we studied only this number of student (around 68,000).

Figure 1 shows an alluvial plot of such students, mobility flows at three milestones of their career: at the macro-area of the region, where they earned high school diploma (origin), at the location of the university, where they received the bachelor's degree, and location of the university, where they enrolled in the first year of master's degree program. The percentage of students in each geographic area that is their place of origin is highlighted in the first stacked bar on the alluvial plot.

The stripes that connect the first stacked bar to the second, which represent the location of the universities from which the bachelor's degrees were obtained, clearly show that most of the connections are from the South to the Center and to the North, while the other incoming flows are negligible. This means that, although the two sets of students are different in size and composition, their main tendencies as depicted by the stripes in Fig. 1 are consistent with the patterns shown in Table 1.

Comparing the data in the three steps, the South and the Islands macro-areas show a progressive decrease in their ability to keep students originating from their areas, from 33.8 to $25.2 \%$ to $18.5 \%$ of students. These findings mean that, at the time of enrollment, about 16,000 students moved from the South and from the Islands to the Center and the North, and around 4500 students followed such direction at the time of enrollment in the first year of a master's degree program. On the contrary, the North-West and the North-East, thanks to their attractiveness, increased their shares by around $8 \%$ and $6 \%$, respectively.

Note that the Center's university mobility figures at both levels are roughly constant, accounting for around $20-22 \%$ in each step. A total of $88.8 \%$ of students who came from 
the Center earned first level degree program in the same macro-area, 5.7\% in the NorthEast, $4.0 \%$ in the North-West, and $2.1 \%$ in the South. Students who came from Lazio enrolled in universities in Campania and Abruzzo, which shows the effect of the "attractiveness" of neighboring geographic areas.

Thus, we can assume that the greatest part of students' mobility phenomenon occurs at the start of their university career. The picture so far depicted is that universities in the South and the Islands, with a few exceptions, can not attract students from other regions and that the domestic student mobility flows are almost entirely unidirectional, on the South-North route. Considering the overall mobility, about $80 \%$ of the total flows on the South-North trajectory are related to the enrollment in the bachelor's degree program, while about the remaining $20 \%$ refers to the additional mobility on the first year of enrollment in a master's degree program. Even tough the latter is not a negligible amount and we are aware that it is a further problematic issue for the South universities, we focus in the next sections only on the first part of the mobility. Understanding the determinants of such mobility and the possible effect of the geographic context, could help policymakers to design policies to promote a kind of engagement in the South universities. For this reason, we now focus only on the mobility at the time of the enrollment in the $1^{\text {st }}$ year of a bachelor's degree program.

\section{Mobility trajectories with respect to specific disciplinary fields (macro-areas level)}

With respect to disciplinary fields and macro-areas of origin and destination, the pattern shown in Table 2 confirms that there are deep differences in the percentages of movers in the disciplinary fields. The overall trend highlights that movements from the NorthWest and the North-East to the South and to the Islands are still negligible. Some students moved from the Center to the South and from the South to te Islands, but these flows are related to border issues, such as flow of students from Reggio Calabria to Messina and vice versa.

Considering the disciplinary field, the most peculiar figures are those related to the healthcare ${ }^{5}$ sector. This field has a different structure, with a restricted number of students and with admission contingent on passing the national entry test. This field was observed to have the highest percentage of stayers in the North-West, the North-East and the Center, and the lowest percentage of stayers in the South and the Islands, compared to the three other fields. The peculiar characteristics of this field enlarged the average size of South-North mobility flows: the admission test seems to increase the gap between universities. Notably, only around $50 \%$ of students of the Healthcare group are stayers in the Islands, while the stayers belonging to the South are the $72 \%$. In this regard, the Center is the main attractor, not the North-West and not the North-East. Thus, most relevant flows are from the Islands to the North-West and the the Center, and from the South to the Center.

As for the Science field, only a negligible percentage of students from the NorthEast moved to the North-West, especially to Turin and Milan. Such area is indeed the leader in this field, keeping its students (93.9\%) and attracting students from all over the 
Table 2 Freshmen in 2014-2015 for macro-area of origin, disciplinary field of study, and macro-area of destination. The percentages are relative to the row

\begin{tabular}{|c|c|c|c|c|c|c|c|}
\hline Origin & $\begin{array}{l}\text { Destination } \\
\text { Field }\end{array}$ & North-West & North-East & Center & South & Islands & Total \\
\hline \multirow{5}{*}{$\begin{array}{l}\text { North- } \\
\text { West }\end{array}$} & Healthcare & 3859 (97.6\%) & $61(1.5 \%)$ & $24(0.6 \%)$ & $5(0.1 \%)$ & $3(0.1 \%)$ & 3952 \\
\hline & Scientific & 19761 (93.9\%) & 932 (4.4\%) & $296(1.4 \%)$ & 39 (0.2\%) & $6(0 \%)$ & 21034 \\
\hline & Social & $17568(94 \%)$ & $751(4 \%)$ & $299(1.6 \%)$ & $42(0.2 \%)$ & $13(0.1 \%)$ & 18673 \\
\hline & Humanities & 10288 (89.4\%) & $1035(9 \%)$ & $166(1.4 \%)$ & 15 (0.1\%) & $2(0 \%)$ & 11506 \\
\hline & Total & $51476(93.3 \%)$ & $2779(5 \%)$ & 785 (1.4\%) & $101(0.2 \%)$ & $24(0 \%)$ & 55165 \\
\hline \multirow[t]{5}{*}{ North-East } & Healtcare & $68(2.2 \%)$ & $2986(95.3 \%)$ & $72(2.3 \%)$ & $4(0.1 \%)$ & $0(0 \%)$ & 3130 \\
\hline & Scientific & $1107(7.2 \%)$ & 14042 (90.8\%) & $288(1.9 \%)$ & $21(0.1 \%)$ & $2(0 \%)$ & 15460 \\
\hline & Social & 797 (6.9\%) & 10430 (90.1\%) & $282(2.4 \%)$ & $53(0.4 \%)$ & $7(0.1 \%)$ & 11569 \\
\hline & Humanities & 301 (3.4\%) & $8226(93.7 \%)$ & $232(2.6 \%)$ & $12(0.1 \%)$ & $1(0 \%)$ & 8772 \\
\hline & Total & $2273(5.8 \%)$ & $35684(91.6 \%)$ & $874(2.2 \%)$ & $90(0.2 \%)$ & $10(0 \%)$ & 38931 \\
\hline \multirow[t]{5}{*}{ Center } & Healtcare & $26(0.6 \%)$ & $65(1.6 \%)$ & $3792(95.7 \%)$ & 77 (1.9\%) & $0(0 \%)$ & 3960 \\
\hline & Scientific & $671(3.8 \%)$ & 683 (3.9\%) & 15800 (89.9\%) & $408(2.3 \%)$ & $2(0 \%)$ & 17564 \\
\hline & Social & 487 (3.5\%) & $550(4 \%)$ & 12484 (90\%) & $346(2.5 \%)$ & $4(0 \%)$ & 13871 \\
\hline & Humanities & $118(1.1 \%)$ & 640 (6.1\%) & 9596 (91\%) & $183(1.7 \%)$ & $4(0 \%)$ & 10541 \\
\hline & Total & $1302(2.8 \%)$ & $1938(4.2 \%)$ & 41672 (90.7\%) & $1014(2.2 \%)$ & $10(0 \%)$ & 45936 \\
\hline \multirow[t]{5}{*}{ South } & Healtcare & $133(2.8 \%)$ & $212(4.5 \%)$ & $963(20.5 \%)$ & $3372(71.8 \%)$ & $16(0.3 \%)$ & 4696 \\
\hline & Scientific & 1804 (8.3\%) & 951 (4.4\%) & $2222(10.1 \%)$ & 16739 (76.6\%) & $126(0.6 \%)$ & 21842 \\
\hline & Social & 1076 (5.9\%) & 713 (3.9\%) & 1719 (9.5\%) & $14271(78.8 \%)$ & 330 (1.82\%) & 18109 \\
\hline & Humanities & $390(3.5 \%)$ & $556(4.9 \%)$ & $1172(10.4 \%)$ & $8941(80 \%)$ & $108(0.9 \%)$ & 11167 \\
\hline & Total & $3403(6.1 \%)$ & $2432(4.4 \%)$ & $6076(10.8 \%)$ & $43323(77.6 \%)$ & $580(1 \%)$ & 55814 \\
\hline \multirow[t]{5}{*}{ Islands } & Healtcare & 342 (17.9\%) & 173 (9.1\%) & 362 (18.9\%) & 37 (1.9\%) & 995 (52.1\%) & 1909 \\
\hline & Scientific & $1225(14.6 \%)$ & 279 (3.3\%) & $591(7.1 \%)$ & $82(0.9 \%)$ & 6196 (73.9\%) & 8373 \\
\hline & Social & $530(7.2 \%)$ & 337 (4.6\%) & $564(7.7 \%)$ & $55(0.7 \%)$ & $5844(79.7 \%)$ & 7330 \\
\hline & Humanities & $262(6.4 \%)$ & 325 (7.9\%) & 381 (9.3\%) & $56(1.4 \%)$ & $3089(75.1 \%)$ & 4113 \\
\hline & Total & $2359(10.8 \%)$ & $1114(5.1 \%)$ & 1898 (8.7\%) & $230(1.1 \%)$ & 16124 (74.2\%) & 21725 \\
\hline \multirow[t]{5}{*}{ Total } & Healtcare & 4428 (25\%) & 3497 (19.8\%) & $5213(29.5 \%)$ & $3495(19.8 \%)$ & 1014 (5.7\%) & 17647 \\
\hline & Scientific & $24568(29.1 \%)$ & $16887(20 \%)$ & 19197 (22.7\%) & $17289(20.5 \%)$ & $6332(7.5 \%)$ & 84273 \\
\hline & Social & 20458 (29.4\%) & $12781(18.3 \%)$ & $15348(22 \%)$ & 14767 (21.2\%) & 6198 (8.9\%) & 69552 \\
\hline & Humanities & 11359 (24.6\%) & $10782(23.3 \%)$ & 11547 (25\%) & 9207 (19.9\%) & 3204 (6.9\%) & 46099 \\
\hline & Total & 60813 (27.9\%) & 43947 (20.1\%) & 51305 (23.5\%) & $44758(20.5 \%)$ & $16748(7.7 \%)$ & 217571 \\
\hline
\end{tabular}

country. It is the main destination from the Islands (14.6\%), while from the South main destination is still the Center (10.1\%). Once again, no relevant flow is recorded between the South and the Islands. Overall, the most significant mobility paths are from the Islands to the North-West, and from the South to the Center. Moreover, more than 1000 students move from the North-East to the North-West.

Moving to the Social sciences field, the North-West was able to keep $94 \%$ of its students, the North-East kept the $90.1 \%$ and the Center the $90 \%$. For this field, the Islands has kept slightly more students than the South (79.7\% against $78.8 \%)$. Here, the Center generally attracted more than the North, with the North-West always more attractive than the North-East. Overall, the Center, the North-West and the North-East are exchanging a somehow relevant number of students. The highest percentages (of movers on the total number of students in the Macro-Area of origin) are: from the South to the Center (9.5\%), from the Islands to the Center (7.7\%), from the Islands to the North-West (7.2\%) and from the North-East to the North-West (6.9\%). 
Finally, in Humanities field, the South is keeping more students than in the other fields (around $80 \%$ ), while the Islands is keeping around $75.1 \%$. In this case, the North-East is performing better than the North-West, with also a $6 \%$ of students from the Center moving to universities in the North-East. Overall, major flows as they are depicted in Table 2, refer to movements from the South towards the Center (10.4\%), from the Islands towards the Center (9.3\%), from the North-West towards the North-East (9\%) and from the Islands towards the North-East (7.9\%).

The general patterns depicted in Table 2 show that the overall figures on mobility flows significantly changes when specific domains are considered. This observation strongly suggests that some universities play a central role in some degree programs, but are not attractive in other fields of study.

\section{Mobility trajectories of students at a regional level: focus on Southern regions}

The students under analysis presented many university pathways, such as the movements at bachelor's and master's degree levels, dropping out of university after the first year of enrollment, and changing universities or disciplinary fields during their career. Putting our attention on some specific issues related to inter-regional mobility, we outline some of the most important related turning points. In particular, in our exploratory overview of the student mobility data, we focus on (1) the South-North mobility trajectory at glance; (2) the enrollment in specific disciplinary fields (macro-areas level) (3) the mobility trajectories of the students living in specific regions in South Italy.

The regional mobility choices of students, with particular emphasis on those belonging to regions located in the South and the Islands, are shown in Table 3.

Starting from the definition of a mover as a student residing in one region who enrolls as a freshman in a bachelor's degree program in an other region, the percentage of movers is computed as the number of movers in each region out of the total number of students residing in the region (outgoing students). Small regions have the highest percentage of movers (Aosta Valley, 72.2\%; Basilicata, 71.5\%; Molise, 63.8\%, and Trentino Alto Adige, Abruzzo, Calabria, Apulia and Umbria, more than $30 \%$ of movers). Even though regions, such as Apulia, Calabria, and Abruzzo, offer more than one university to their students, around one student out of three from these regions choose other destinations. The regions with a low percentage of movers are the ones with the biggest and greatest number of universities: Lazio (8.3\%), Lombardy (8.9\%), Tuscany (10.6\%), EmiliaRomagna (14.2\%) and Campania (14.2\%). Campania presents a behavior in attracting students of its territory in line with other regions in the Center and North, even better than Piedmont (16.3\%) and Veneto (21.8\%). The trend in the Islands is similar to those in the smaller regions of the Center and the North, with $18.7 \%$ of movers in Sardinia and $28.2 \%$ of movers in Sicily. In summary, the percentage of movers is significantly high in small regions and in the South, expect for the Campania region. Regarding the attractiveness of universities, the ratio of incoming freshmen to the number of students living in a region is used to signal the presence of attractive locations. Trentino Alto Adige (44.8\%), Emilia Romagna (35.2\%), Abruzzo (39.8\%), Marche (32.1\%) and Molise (47.5\%) show the highest values. The regions with the lowest values are in the South and the Islands: Sardinia (0.3\%), Calabria (2.2\%), Apulia (4.9\%), Sicily (5.0\%) and Campania 


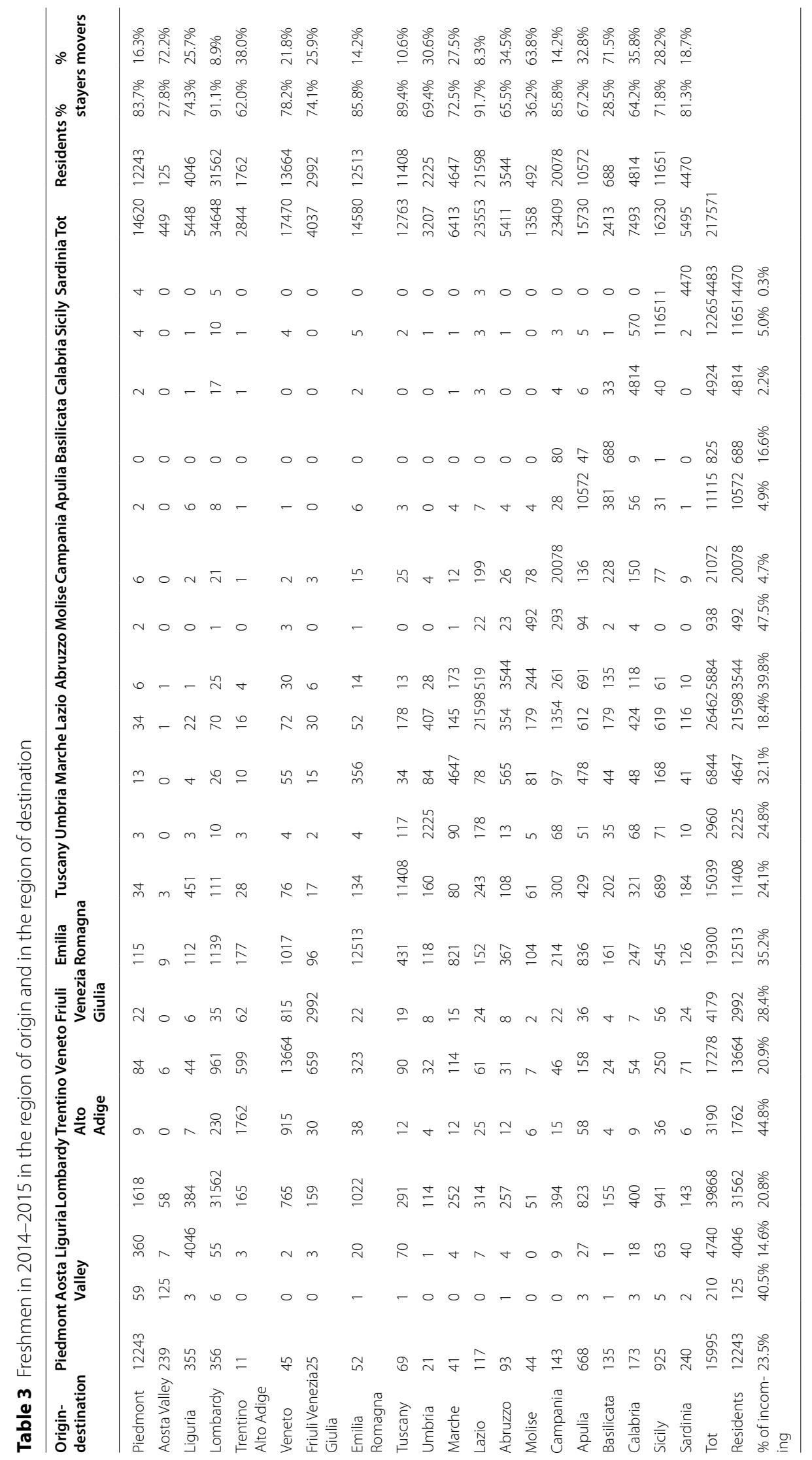


(4.7\%). In addition, small regions have a higher propensity to both export (outgoing) and import (incoming) students compared to the other regions.

The exploratory analysis has shown some peculiar patterns in the students' mobility choices in Campania: the region's outgoing student flows from the place of residence to a bachelor degree's program university are not as relevant as those of the other South regions but behave similarly to the flows observed in the Center and the North. Even though Campania is not a good importer region, its universities attract students from neighboring regions.

Hence, to assess the factors that determine the probability of being a mover from the Campania region, a confirmatory approach is used and is discussed in Section "Modeling the probability of being a mover".

\section{Modeling the probability of being a mover}

To assess whether the local context affects the individual choice to enroll in a university outside the Campania region, the model outcome is defined as a binary variable equal to 1 if the student decides to move to universities outside the region of residence (movers category) and 0 if the student is enrolled in a bachelor's degree program in the region of residence (stayers category). The model includes covariates of individual characteristics and one grouping variable related to high schools that captures the effect of the local context, interpreted as both socioeconomic background and life experiences (Table 4).

To model such hierarchical data structure inherent in university students' mobility, we adopted multilevel logistic regression models Snijders and Bosker (2011); Bates et al. (2015) with two levels. The units of analysis in level-1 were 22676 students, i.e., the freshmen enrolled in the Italian university system in the academic years 2014-2015 who reside in the Campania region. ${ }^{6}$ Then the level- 1 covariates are related to the students' sociodemographic characteristics and their scholastic pathway before starting their university career. The upper level of analysis (level-2) is related to the grouping variable that considers the specific high school attended by the cohort under analysis. In the database, each high school is identified by a unique national alphanumeric code, the so-called mechanographic code, and we use such codes as categories of the second-level variable. The distribution of high schools in Campania region by province and type is provided in Table 5. We assess if there is an additional random effect related to each school that can be estimated given the fixed effects. More specifically, we want to evaluate if there are some schools that show either a greater or a lower probability of having movers among their pupils.

To connect covariates to the outcome variable, a logit link is used. The corresponding probability $\pi_{i j}$ is defined as the probability that the $i$ th student belonging to the $j$ th high school will enroll in a bachelor's degree program outside the Campania region, given both the fixed and the random effects. In general, a multilevel random intercept logistic model with $p$ covariates $x_{h i j}, h=1, \ldots, p$, measured at level-1, and $q$ covariates $z_{k j}, k=1$, $\ldots, q$ measured at level-2 is estimated:

\footnotetext{
${ }^{6}$ Note that for the model estimation, due to the relevant role played by the high school attended, we discarded 539 students residing in the Campania region with a diploma obtained in a high school outside the Campania region or having missing information about their high school in the MOBYSU.IT database.
} 
Table 4 Variables of the models

\begin{tabular}{|c|c|c|c|}
\hline Variables & Meaning & $\begin{array}{l}\text { Kind of attributes (role in } \\
\text { the model) }\end{array}$ & Values \\
\hline \multirow[t]{5}{*}{ Province } & \multirow[t]{5}{*}{$\begin{array}{l}\text { Province of residence of the } \\
\text { student }\end{array}$} & \multirow[t]{5}{*}{$\begin{array}{l}\text { Sociodemographic variables } \\
\text { (fixed effect) }\end{array}$} & $\begin{array}{l}{[\mathrm{NP}]=\text { Naples (Napoli, refer- }} \\
\text { ence) }\end{array}$ \\
\hline & & & Avellino \\
\hline & & & Benevento \\
\hline & & & Caserta \\
\hline & & & Salerno \\
\hline \multirow[t]{2}{*}{ Gender } & \multirow[t]{2}{*}{ Gender (binary) } & \multirow{2}{*}{$\begin{array}{l}\text { Individual socio-demo- } \\
\text { graphic (fixed effect) }\end{array}$} & {$[\mathrm{F}]=$ Female (reference) } \\
\hline & & & {$[\mathrm{M}]=$ Male } \\
\hline \multirow[t]{6}{*}{ Diploma } & \multirow{6}{*}{$\begin{array}{l}\text { Kind of high school diploma } \\
\text { achieved }\end{array}$} & \multirow{6}{*}{$\begin{array}{l}\text { Individual scholastic achieve- } \\
\text { ment (fixed effect) }\end{array}$} & Scientific lyceum (reference) \\
\hline & & & Other lyceum \\
\hline & & & Classical lyceum \\
\hline & & & Other diploma \\
\hline & & & Vocational diploma \\
\hline & & & Technical diploma \\
\hline Grade & $\begin{array}{l}\text { Scaled grade in diploma } \\
\text { achievement }\end{array}$ & $\begin{array}{l}\text { Individual scholastic achieve- } \\
\text { ment (fixed effect) }\end{array}$ & $\begin{array}{l}\text { Range from: }-1.7105 \text { (corre- } \\
\text { sponds to } 60, \text { minimum) } \\
\text { to }+1.7105 \text { (corresponds to } \\
100 \text { cum laude, maximum) }\end{array}$ \\
\hline \multirow[t]{2}{*}{ Paritaria } & \multirow[t]{2}{*}{ Private schools } & \multirow{2}{*}{$\begin{array}{l}\text { Individual scholastic achieve- } \\
\text { ment (fixed effect) }\end{array}$} & {$[0]=$ State school (reference) } \\
\hline & & & {$[1]=$ Non-private school } \\
\hline \multirow[t]{4}{*}{ Field of study } & \multirow{4}{*}{$\begin{array}{l}\text { The macro-area of study in } \\
\text { which the student enroll } \\
\text { (disciplinary field) }\end{array}$} & \multirow[t]{4}{*}{$\begin{array}{l}\text { Degree in which they enroll } \\
\text { (fixed effect) }\end{array}$} & $\begin{array}{l}{[S C I E N T I F I C]=\text { Scientific Area }} \\
\text { (reference) }\end{array}$ \\
\hline & & & $\begin{array}{l}{[\text { HEALTHCARE }]=\text { Healthcare }} \\
\text { Area }\end{array}$ \\
\hline & & & {$[\mathrm{SOCIAL}]=$ Social Area } \\
\hline & & & $\begin{array}{l}\text { [HUMANITIES] = Humanities } \\
\text { Area }\end{array}$ \\
\hline School code & $\begin{array}{l}\text { The unique code to denote } \\
\text { each school }\end{array}$ & $\begin{array}{l}\text { Individual scholastic achieve- } \\
\text { ment (random effect) }\end{array}$ & $\begin{array}{l}\text { Unique national code for each } \\
\text { school }\end{array}$ \\
\hline \multirow[t]{2}{*}{ OUTCOME } & \multirow[t]{2}{*}{$\begin{array}{l}\text { Migratory choose of stu- } \\
\text { dent when they enroll }\end{array}$} & \multirow[t]{2}{*}{$\begin{array}{l}\text { Degree in which they } \\
\text { enroll (outcome/response) }\end{array}$} & $\begin{array}{l}{[0]=\text { Enroll in region Campa- }} \\
\text { nia (reference) }\end{array}$ \\
\hline & & & {$[1]=$ Enroll in other regions } \\
\hline \multirow[t]{3}{*}{$\begin{array}{l}\text { Municipal- } \\
\text { ity_Size }\end{array}$} & \multirow[t]{3}{*}{$\begin{array}{l}\text { Demographic size of munici- } \\
\text { pality of residence of student }\end{array}$} & \multirow[t]{3}{*}{$\begin{array}{l}\text { Individual soc.-demo. (fixed } \\
\text { effect, not significant) }\end{array}$} & $\begin{array}{l}{[S M A L L]=<15000 \text { inhabit- }} \\
\text { ants }\end{array}$ \\
\hline & & & $\begin{array}{l}{[M E D / U M]=>15000 \text { inhabit- }} \\
\text { ants; }<50000 \text { inhabitants }\end{array}$ \\
\hline & & & {$[B \mid G]=>50000$ inhabitants } \\
\hline . & $h=1$ & & (1) \\
\hline
\end{tabular}

where $\sigma_{u 0}^{2}$ is the level-2 variance component, and $\operatorname{logit}\left(\pi_{i j}\right)$ is the logit transformation or $\log$-odds ratio transformation $\log \left(\pi_{i j} /\left(1-\pi_{i j}\right)\right)$. The $\beta_{0 j}$ coefficient represents the random intercept, while the $\beta_{h}$ and $\beta_{k}$ coefficients are the fixed effects of level- 1 and level2 , respectively. The fixed effects do not vary across students and high schools, and can be viewed as the average effects over the entire population of individuals nested in the 
Table 5 All the 1069 schools in the Campania region included in Model 1, grouped by province and type. The percentages are relative to the row

\begin{tabular}{lllllll}
\hline $\begin{array}{l}\text { Province/type } \\
\text { of school }\end{array}$ & $\begin{array}{l}\text { Scientific } \\
\text { Lyceum }\end{array}$ & $\begin{array}{l}\text { Other } \\
\text { Lyceum }\end{array}$ & $\begin{array}{l}\text { Classical } \\
\text { Lyceum }\end{array}$ & Other & $\begin{array}{l}\text { Vocational } \\
\text { track }\end{array}$ & Technical track \\
\hline $\begin{array}{l}\text { Naples }(N= \\
483)\end{array}$ & $113(23 \%)$ & $73(15 \%)$ & $37(7 \%)$ & $14(2 \%)$ & $74(15 \%)$ & $172(35 \%)$ \\
$\begin{array}{l}\text { Avellino }(N \\
=95)\end{array}$ & $22(23 \%)$ & $15(15 \%)$ & $13(13 \%)$ & $2(2 \%)$ & $14(14 \%)$ & $29(30 \%)$ \\
$\begin{array}{l}\text { Benevento }(N \\
=76)\end{array}$ & $16(21 \%)$ & $4(5 \%)$ & $13(17 \%)$ & $0(0 \%)$ & $16(21 \%)$ & $27(35 \%)$ \\
$\begin{array}{l}\text { Caserta }(N= \\
261)\end{array}$ & $67(25 \%)$ & $37(14 \%)$ & $19(7 \%)$ & $9(3 \%)$ & $30(11 \%)$ & $99(37 \%)$ \\
$\begin{array}{l}\text { Salerno }(N= \\
154)\end{array}$ & $28(18 \%)$ & $20(12 \%)$ & $19(12 \%)$ & $1(0 \%)$ & $29(18 \%)$ & $57(37 \%)$ \\
\hline
\end{tabular}

schools. To this basic multilevel model, it is possible to add random slopes for the level-1 variables: some $\beta_{h}$ coefficients become $\beta_{h j}=\beta_{h}+u_{h j}, u_{h j} \sim N\left(0, \sigma_{u h}^{2}\right)$, giving rise to the covariances among the error terms $u_{h j}$ and the interaction effects within variables of the same level-1 or cross-levels.

Different procedures have been implemented for the estimation of multilevel logistic regression models Goldstein (2005); Browne and Rasbash (2009); Rasbash et al. (2005). The algorithm used in this study, which is included in the R software considering the lme 4 and nlme packages, is the so-called BOBYQA, an iterative procedure for finding a minimum of a function given boundaries (Powell, 2007, 2009). Due to the unavailability of the likelihood ratio test in the multilevel logistic regression model Rasbash et al. (2012), the significance of the $\sigma_{u 0}^{2}$ parameter is tested using the Wald test. The best model is selected according to the minimum AIC criterion. The intraclass correlation coefficient (ICC), also called variance partition coefficient (VPC), which shows the variance partitioning (i.e., the percentage of the variance at level-2), is computed by evaluating $\sigma_{u 0}^{2} /\left(\sigma_{u 0}^{2}+3.29\right)$, where 3.29 is the variance of the logistic distribution for level-2 Snijders and Bosker (2011); Van Duijn et al. (1999).

\section{Main results}

The variables of the model, as described in Table 4, are linked to different individual aspects, such as: (1) socio-demographic characteristics, (2) scholastic achievement, (3) the degree program in which the student is enrolled. The variable selection process has been performed according to the AIC criterion, and the only not significant variable was the demographic size of the municipality of the student's residence.

We estimated and reported two models, summarized in Table 6, following Eq.1. We estimated Model 1 by considering all the students, and Model 2 by excluding students enrolled in a healthcare degree program. As shown in "The data" section, healthcare students follow different career patterns, and their migration dynamics could present some peculiarities compared with the other university disciplinary fields due also to the requirement to pass a national exam to be eligible for the enrollment. The bold numbers in Table 6 denote the significant effects. Some variables, although with not significant coefficients such as in the case of "Paritaria" school, can be used to improve the quality 
of the model in terms of the AIC criterion. All the potential interaction effects were computed analogously, and only those that improved the goodness of fit of the model were kept.

In both models, we note that most of the results, in terms of the main effects, are similar, showing some common consolidated patterns. The main differences are the marginal effect of the category Other lyceum (its effect is positive and significant in Model 1 but is not significant in Model 2), and the interaction effect between the gender and the high school grade (it is significant only in Model 2).

As shown in Fig. 2, healthcare studies have a remarkable high odds ratio due to the following factors: the admission of a restricted number of students who need to pass a national entrance test (which means the top students in the country can choose their university destination ahead of the other students), and the guarantee, in most degree programs in this disciplinary field, of a job immediately after graduation, even in the southern regions with a poor job market. Given all these aspects, it is clear that the mobility behavior of healthcare students is much higher that students in other fields. Furthermore, this category has a negative interaction effect with high school grades, showing that the best students who are interested in healthcare programs decide to stay in the Campania region, whereas it can be argued that for other disciplinary fields, the migration dynamics go into the opposite direction, i.e., students with high grade are more likely to migrate.

For the sake of brevity, in the following section we will discuss in detail only the results of Model 2, as they are almost the same as the results of Model 1.

\section{Interpretation of fixed components}

In line with well-established results in the literature on the mobility of university students, we observe a gender effect, in which males are more likely to migrate than females (Fig. 3) especially according to the South-North migration pathway.

No significant effect of the high school grade has been found, while the type of high school attended by the students (Fig. 4) significantly explained the tendency to enroll in a degree program in another Italian region. Students attending a classical lyceum or another lyceum tend to migrate more than those attending a scientific lyceum (the reference category). Students of technical schools seem to have a significantly lower inclination to migrate (Table 6), and in general, students from technical and vocational high schools have a lower university enrollment rate compared than students from lyceum schools. A significant effect is shown for private schools (Fig. 2). Within this category, there are very different kinds of schools, but they are usually more expensive than public schools, so it could be reasonable to assume that families of students in private schools have the economic conditions needed to sustain these students' university pathways in other regions.

The province effect (Fig. 5) shows that Benevento is suffering much more than other provinces from the outflow of students, followed by Avellino, due to the scarcity or absence of university degree programs in those provinces and the considerable distance of some parts of these provinces from universities. Salerno, instead, shows a lower value of the effect, because its university, which is near the city, is attractive especially to students living in the towns in the North of the province. Naples, thanks to the presence 
there of the biggest university in South Italy in terms of the number of students enrolled, which is also the oldest public university, and of many other universities, maintains a central role in attracting a multitude of internal students who decide to enroll in a degree program within the regional borders.

Figure 6 highlights the marginal effects estimated by the model considering the three disciplinary macro-areas, except of healthcare category. The students enrolled in social studies degree programs have the highest inclination to migrate, while students enrolled in humanities and science degree programs have the highest percentage of stayers.

Several interaction effects are worth to be explored. The first is the significant interaction between males and technical schools (Fig. 7), which shows that only on this type of high school is there an additional gender effect. A lower percentage of males (10\%) from technical schools enroll in universities and tend to migrate to other regions compared to males from other types of schools, while for females, the percentage is $6.8 \%$. The interaction effects of high school grade related to both the disciplinary macro-area and the gender (Figs. 8 and 9, respectively) are also significant. In addition, male students with a high grade and who want to enroll in a social studies degree program are more inclined to be movers.

Furthermore, it seems that for some disciplinary fields (science and humanities macroareas), the universities in Campania can keep good students from high school, so it is plausible that a prestige effect is implicitly considered as well as the variety of the degree programs available. For social studies, students with high grades are more willing to try enrolling in other universities outside their region of residence.

\section{The interpretation of random components}

Among the random effects shown in the Model 2 (Table 6), the impact of the high school attended is very strong on the overall $R^{2}$, which was seen by comparing the marginal $R^{2}$ with the conditional $R^{2}$. The effect of the type of school attended, was found to strongly affects the probability of a student being a mover, which is considered a fixed effect. However, by introducing the specific high school attended, i.e., the school code, as a random effect of the second level, we observed a Intra-Class-Correlation (ICC) with a not negligible size, and a doubling of the value of the goodness of fit measure (see marginal and conditional $R^{2}$ values in Table 6). Hence, these effects, which account for considerable part of the overall variation in the probability of a student migrating to other regions, are related to the different schools in the Campania region. Many factors, such as the socioeconomic status of the student's family and the geographic location of the school, play a central role in the choice of students belonging to the same school to migrate or not to enroll in a university degree program.

We observed 112, over 1069 schools, significant random effects, with both positive and negative coefficients, on around $10 \%$ of all the high schools included in the data. We noticed that most of such schools are concentrated in a few municipalities. Sometimes, all the high schools in a single municipality showed significant effects. Thus, we decided to aggregate the significant effects by averaging them across the municipalities, and to visualize them in a choropleth map (Fig. 10) with the municipalities (light gray-lines) nested into the five provinces (dark gray-lines). 
Table 6 Two multilevel logistic regression models: the first with students enrolled in healthcare programs, and the second without

\begin{tabular}{|c|c|c|c|c|c|c|}
\hline \multirow[t]{2}{*}{ Fixed effects } & \multicolumn{3}{|c|}{ Model 1 (With healtcare) } & \multicolumn{3}{|c|}{ Model 2 (No healtcare) } \\
\hline & OddsRatios & Conf.Int (95\%) & $P$-Val & OddsRatios & Conf.Int (95\%) & $P$-Val \\
\hline (Intercept) & 0.03 & $0.02-0.03$ & $<0.001$ & 0.02 & $0.02-0.03$ & $<0.001$ \\
\hline Avellino & 5.49 & $4.14-7.29$ & $<0.001$ & 8.25 & $5.94-11.44$ & $<0.001$ \\
\hline Benevento & 11.01 & $8.01-15.13$ & $<0.001$ & 15.37 & $10.71-22.06$ & $<0.001$ \\
\hline Caserta & 3.49 & $2.76-4.42$ & $<0.001$ & 4.00 & $3.01-5.32$ & $<0.001$ \\
\hline Salerno & 4.26 & $3.38-5.35$ & $<0.001$ & 5.85 & $4.46-7.69$ & $<0.001$ \\
\hline Other lyceum & 1.30 & $1.05-1.61$ & 0.015 & 1.04 & $0.82-1.33$ & 0.729 \\
\hline Classical lyceum & 1.44 & $1.15-1.80$ & 0.002 & 1.36 & $1.06-1.75$ & 0.017 \\
\hline Other diploma & 0.67 & $0.35-1.31$ & 0.243 & 0.83 & $0.40-1.68$ & 0.597 \\
\hline Vocational track & 1.13 & $0.80-1.60$ & 0.474 & 0.86 & $0.57-1.30$ & 0.487 \\
\hline Technical track & 0.66 & $0.52-0.85$ & 0.001 & 0.48 & $0.36-0.65$ & $<0.001$ \\
\hline Gender $=$ Male & 1.24 & $1.08-1.42$ & 0.002 & 1.16 & $1.00-1.35$ & 0.049 \\
\hline Grade (scaled) & 1.08 & $0.98-1.19$ & 0.139 & 1.04 & $0.94-1.16$ & 0.432 \\
\hline $\begin{array}{l}\text { Healthcare } \\
\text { studies }\end{array}$ & 8.09 & $6.93-9.44$ & $<0.001$ & & & \\
\hline Social studies & 2.25 & $2.01-2.53$ & $<0.001$ & 2.40 & $2.13-2.70$ & $<0.001$ \\
\hline $\begin{array}{l}\text { Humanities } \\
\text { studies }\end{array}$ & 1.21 & $1.05-1.40$ & 0.010 & 1.27 & $1.09-1.47$ & 0.002 \\
\hline Non-state school & 1.25 & $0.96-1.62$ & 0.096 & 1.27 & $0.93-1.73$ & 0.135 \\
\hline $\begin{array}{l}\text { Other lyceum * } \\
\text { Male }\end{array}$ & 1.24 & $0.85-1.82$ & 0.263 & 1.47 & $0.98-2.22$ & 0.064 \\
\hline $\begin{array}{l}\text { Classical lyceum } \\
{ }^{*} \text { Male }\end{array}$ & 1.26 & $0.96-1.65$ & 0.093 & 1.31 & $0.98-1.74$ & 0.067 \\
\hline $\begin{array}{l}\text { Other diploma * } \\
\text { Male }\end{array}$ & 0.41 & $0.14-1.18$ & 0.099 & 0.61 & $0.20-1.88$ & 0.389 \\
\hline $\begin{array}{l}\text { Vocational track } \\
\text { * Male }\end{array}$ & 0.94 & $0.61-1.47$ & 0.798 & 0.84 & $0.49-1.45$ & 0.528 \\
\hline $\begin{array}{l}\text { Technical track * } \\
\text { Male }\end{array}$ & 1.43 & $1.10-1.87$ & 0.008 & 1.68 & $1.23-2.30$ & 0.001 \\
\hline $\begin{array}{l}\text { Male * Grade } \\
\text { (scaled) }\end{array}$ & 1.07 & $0.97-1.18$ & 0.154 & 1.12 & $1.01-1.25$ & 0.029 \\
\hline $\begin{array}{l}\text { Grade }(\text { scaled) * } \\
\text { Healthcare }\end{array}$ & 0.45 & $0.39-0.52$ & $<0.001$ & & & \\
\hline $\begin{array}{l}\text { Grade (scaled)* } \\
\text { Social }\end{array}$ & 1.20 & $1.07-1.34$ & 0.001 & 1.22 & $1.09-1.37$ & 0.001 \\
\hline $\begin{array}{l}\text { Grade }(\text { scaled) * } \\
\text { Humanities }\end{array}$ & 0.93 & $0.81-1.07$ & 0.337 & 0.95 & $0.82-1.10$ & 0.469 \\
\hline \multicolumn{7}{|l|}{ Random effects } \\
\hline$\sigma^{2}$ & 3.29 & & & 3.29 & & \\
\hline$\tau_{00}$ & 1.06 School_Code & & & 1.47 School_Code & & \\
\hline ICC & 0.24 & & & 0.31 & & \\
\hline $\mathrm{N}$ & 1069 School_Code & & & 1031 School_Code & & \\
\hline Observations & 22676 & & & 20669 & & \\
\hline $\begin{array}{l}\text { Marginal } R^{2} / \\
\text { Conditional } R^{2}\end{array}$ & $0.208 / 0.401$ & & & $0.192 / 0.442$ & & \\
\hline
\end{tabular}

First of all, all the five provinces presented significant random effects. In the city of Naples, 12 schools had a positive effect. This means that these schools had an additional effect that encouraged some students to leave their region of origin for university 


\section{Odds ratios Model 1}

Avellino Province -

Benevento Province -

Caserta Province -

Salerno Province -

Other Lyceum -

Classical Lyceum -

Other type -

Vocational track -

Technical track -

Gender: Male -

Scaled Grade -

Healthcare Studies -

Social Studies -

Humanities Studies -

Private School type -

Other Lyceum * Male -

Classical Lyceum * Male -

Other Diploma * Male -

Vocational * Male -

Tecnhical * Male -

Male * Grade -

Grade * Healtchare -

Grade * Social -

Grade * Humanities -

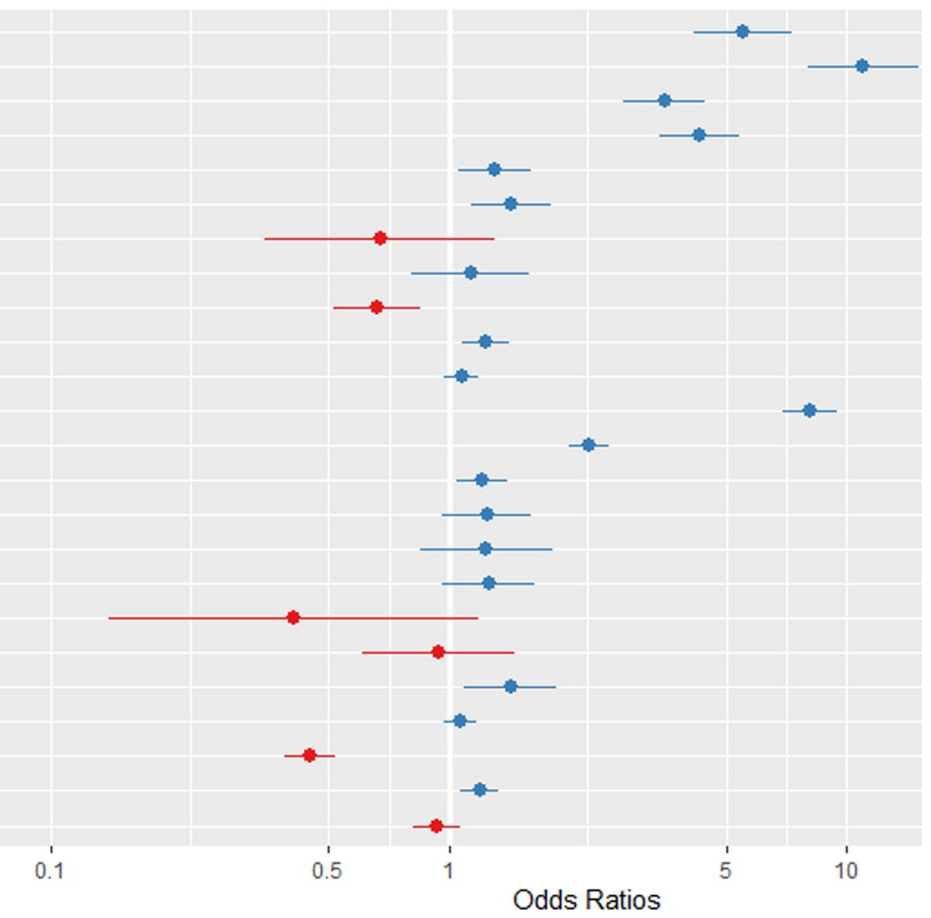

Fig. 2 Model 1: marginal effects as odds ratios

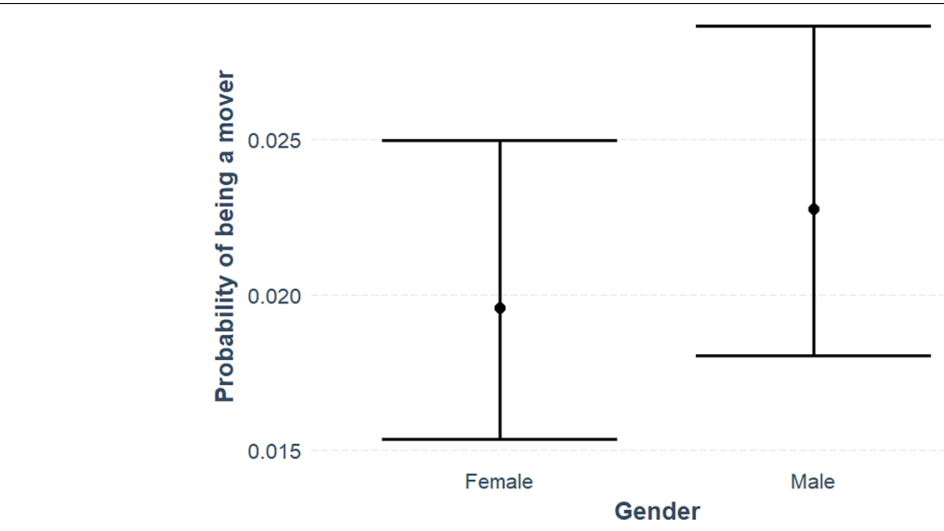

Fig. 3 Model 2: estimated marginal probabilities with respect to gender

studies. These schools are mainly different types of lyceums located in geographic areas that are generally considered quite wealthy. For some of them, the mobility rate reached $20 \%$. The main destinations were private universities, especially in Milan and Rome, considered among the best in Italy according to several rankings (which shows the prestige-status effect). In the other main cities, i.e., Salerno, Avellino, and Caserta, except for Benevento, we observed both positive and negative random effects. For such cases, there seems to be no clear explanation. As For example, in Avellino city, there are two lyceums that significantly differ from the other schools. One had a mobility rate equal to $43 \%$, and the other had a negative random effect showed by a migration rate of only $4 \%$. For 


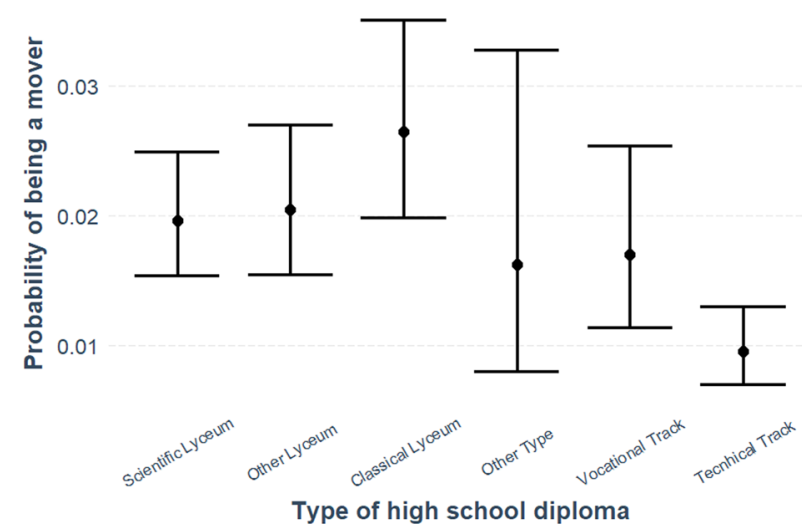

Fig. 4 Model 2: estimated marginal probabilities with respect to high school diploma type

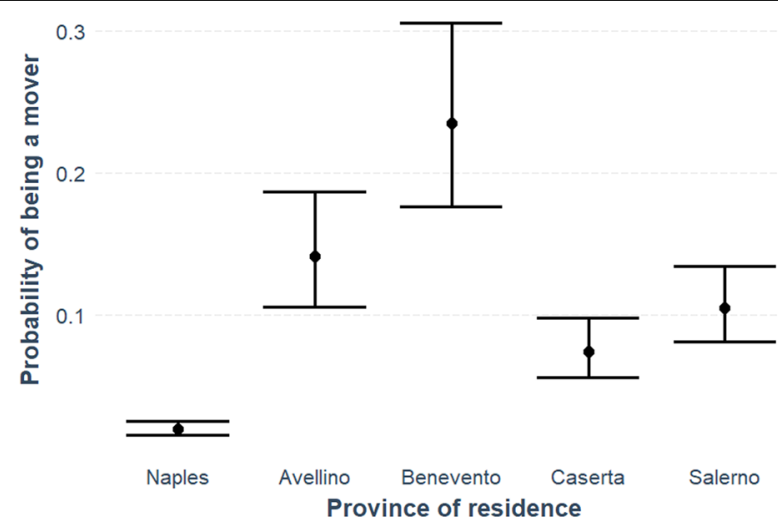

Fig. 5 Model 2: Estimated marginal probabilities with respect to provinces of residence

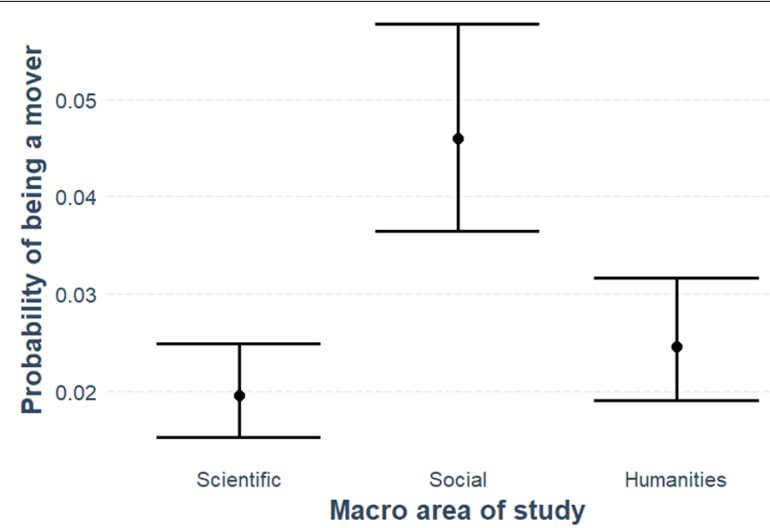

Fig. 6 Model 2: Estimated marginal probabilities with respect to the macro-area of study

smaller municipalities located in provinces, we noted the presence of some geographic clusters. Note that the real sizes of the geographic cluster are larger then those depicted, because we highlighted only the municipalities, where the high schools are located, and not all the municipalities gravitating towards such schools. 


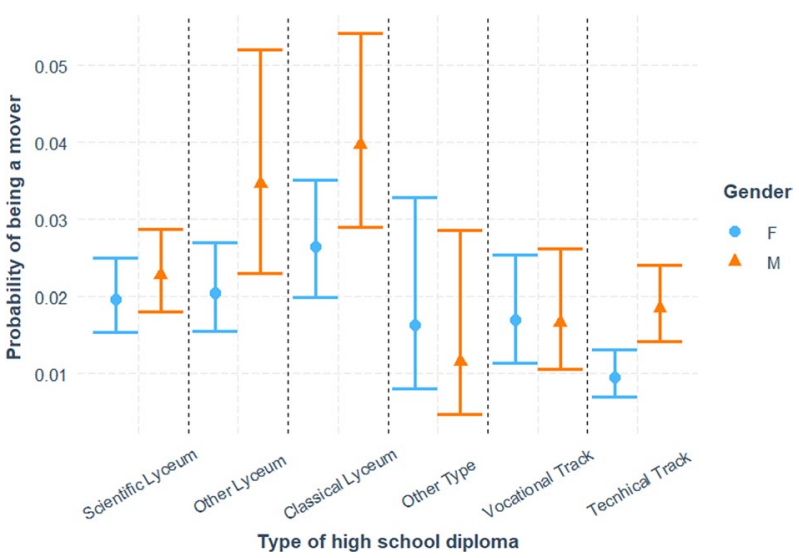

Fig. 7 Model 2: estimated marginal probabilities of the interaction between high school diploma type and gender

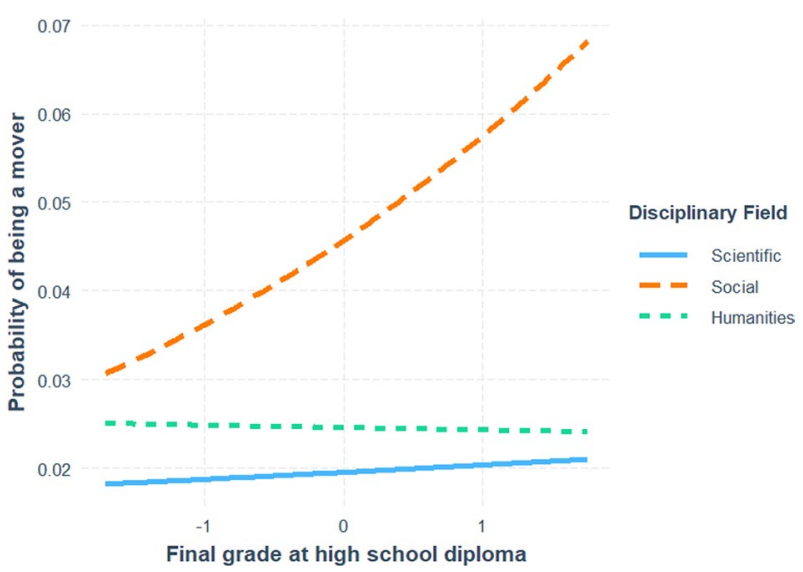

Fig. 8 Model 2: Estimated marginal probabilities of the interaction between the scaled high school final grade and the macro-area of study

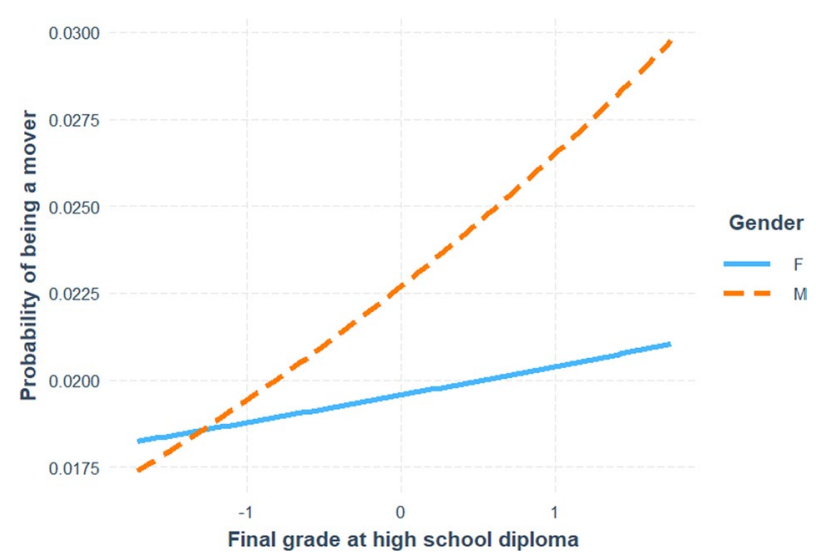

Fig. 9 Model 2: Estimated marginal probabilities of the interaction between the scaled high school final grade and the gender 


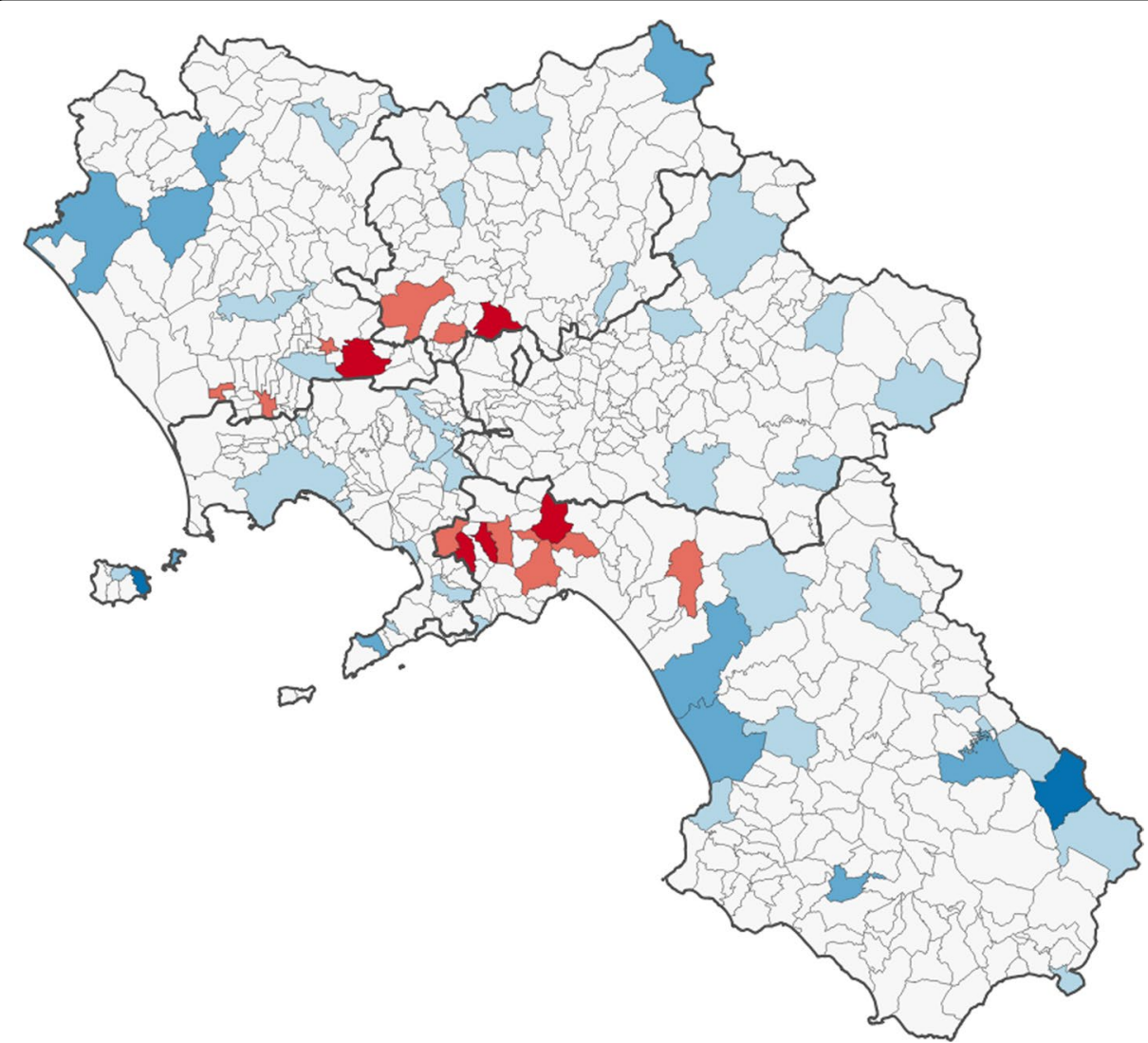

Fig. 10 Model 2: Random effects for each municipality. If more schools belong to same municipality, the average effect is computed. Blue color: positive effects; red color, negative effects; white color, not significant effects

Thus, to better outline these mobility dynamics, we explicitly identify now seven clusters of municipalities, according to their random effects (positive or negative, as mentioned obtained averaging schools effects) and their geographic location, and we will deepen their main destinations (in Campania and outside Campania) and their overall percentages of movers and stayers.

- Cluster1, the municipalities of Sessa Aurunca, Vairano Patenora, and Teano.

- Cluster2, the municipalities of San Bartolomeo in Galdo, Morcone, San Giorgio del Sannio, and Guardia Sanframondi.

- Cluster3, the municipalities of Teggiano, Padula, Sala Consilina, Sant'Arsenio, and Montesano sulla Marcellana.

- Cluster4, the municipalities of Ischia, Casamicciola Terme, Procida, Gragnano, Meta di Sorrento, and Sorrento.

- Cluster5, the municipalities of Eboli, Campagna, Agropoli, Capaccio, and Roccadaspide.

- Cluster6, the municipalities of Aversa, San Cipriano d'Aversa, and San Nicola la Strada.

- Cluster7, the municipalities of Nocera, Angri, Pagani, Roccapiemonte, Baronissi, Mercato San Severino, and Cava de' Tirreni. 
These clusters are briefly described in Table 7 . We can clearly state that first five clusters have a clear predominance of bordering universities as main destinations for the movers. Comparing cluster 1 and cluster6, both of them comprise Municipalities in the Province of Caserta, where the main destination is the Vanvitelli University of Campania (with $41.1 \%$ on the overall numbers of stayers), while movers from that Province go mainly to the University of Cassino and Southern Lazio (4.7\%). Cluster1 has a switch in the leadership role, with the University of Cassino and Southern Lazio being the most chosen, even more than any university in Campania. On the other hand, cluster6 has a strong connection with the Vanvitelli University of Campania (4\% more than the average level of the province). Cluster2 is affected by the border effect of the University of Molise, a small university that attracts students from the bordering municipalities in the Province of Benevento. Cluster1 comprises municipalities in the Province of Salerno, but which are far from the University of Salerno. They are affected by the neighboring University of Basilicata (which has $11 \%$ in this cluster, compared to the $1.6 \%$ of the Province of Salerno) and their students are less inclined to go to the University of Salerno (54.8\% is the average of the Province of Salerno, while for these municipalities, it is only 30\%). Cluster4 is characterized by a decrease in the percentages of students, residing in the Province of Naples, who enroll in the University of Naples Federico II (43\% compared to the $56.8 \%$, that is the average level in the Province of Naples). Students from the islands (Ischia, and Procida) and from the Sorrento Peninsula are more likely to move to Milan, Turin, and especially Rome than the average. Furthermore, students of cluster5, from the coastal area of Cilento (Province of Salerno) are less likely to enroll in the University of Salerno (46\% compared to the $54.8 \%$ in that Province), and spread all over the Country (35\% of movers compared to the regional $12 \%$ ). Cluster7 is clearly affected by the closeness of these municipalities to the campus of the University of Salerno located in Fisciano. While the overall percentages of movers are similar to the regional values, it must be stressed that those are random effects, so given all the fixed effects of the model, the power of attraction of the University of Salerno is still significant for the students coming from schools in these municipalities.

Overall, we can almost entirely explain these random effects as: (1) local hub effect of some universities (Federico II University of Naples, Vanvitelli University of Campania, and University of Salerno) that encouraged students from the surrounding areas to enroll there, thereby reducing their expected quota of movers, (2) a bordering effect, with students attending schools in municipalities close to the regional borders and far from main headquarters of regional universities, who are more inclined to pursue studies in other regions but mainly on a commuting arrangement, leading to an excess in the expected number of movers, and (3) high status mobility of students who are not so far from regional universities but are residing in municipalities with a higher propensity (from the historical, logistical, and economical point of view) to mobility. These students are more likely to go to the big metropolitan areas in the Center and in the North, experimenting on migration rather than mobility.

Considering the discovered territorial clusters, together with the preferred destinations and the patterns shown by the random effects, some types of movers can be discussed: 
- false movers or border students, i.e., students living in inland areas close to the the regional border, far from the main universities in the Campania Region and more closer to other universities outside the region. This is the case of cluster located on the northern part of the Caserta province, in which students move towards universities in Rome and to the University of Cassino and Southern Lazio. Similar behaviours can be observed both in the cluster located in the eastern part of Benevento province, in which students' main destination is the University of Molise, and in the cluster located to the south-eastern part of the Salerno province, where students are enrolled in the University of Basilicata.

- real movers, i.e., students living in the coastal areas or from the inland. The coastal areas, along with the islands of the Neapolitan archipelago, have massive tourist flows and are thus wealthy. There are also some inlands in Avellino and Salerno provinces that show a high probability of students moving. Looking at the destination universities, we noticed that they are spread equally among universities located in the Center and in the North, especially in the Lazio, Lombardy, Tuscany, and Piedmont regions.

- stayers, characterized by a negative significant effect. There are two main geographic clusters, one of which is centered at the University of Campania Luigi Vanvitelli, and the other, at the University of Salerno located in Fisciano. In these two clusters, we find schools in municipalities from which it is very easy to reach the university campus.

\section{Concluding remarks}

The empirical evidence discussed in this study suggests that individual characteristics and high school as explanatory variables affect the students' migration choices in the Campania region. As the data clearly showed, students are attracted to high-quality universities located in the central-northern regions especially when they want to enroll in a master's degree program, whereas the probability that a student after earning a diploma will move to enroll in a first-level degree is less affected by such motivation linked to high-reputation institutions.

Beside the individual characteristics of a student affecting the probability that he will be a mover, we found that there are some effects that are due to local contexts. The mobility towards private universities and universities with a high reputation seems a prevalent factor in explaining choices of students attending lyceums in main cities. The rest of the outgoing flows are explained either by the habitual crossing of the regional borders mainly by commuting or by mobility to a wide range of universities in the Central and Northern regions.

The road and highway network, the public transportation system, and geographic proximity to regional borders are the main drivers of these kinds of mobility. It is worth noting that the real movers come mainly from some inland parts of the region that are far from big cities and main highways. In such cases, also the enrollment in a university in Campania implies a kind of internal migration within regional borders. That, along with all the other factors, encourages long-distance mobility towards the central and northern parts of the country, which also induces a long-term migration as a way of life. 
Table 7 Seven clusters identified by random effects. Main destinations in Campania and outside the region. Percentages of movers and stayers. First five clusters present negative effects and last two clusters present positive effects

\begin{tabular}{|c|c|c|c|c|}
\hline Cluster & $\begin{array}{l}\text { Campania destinations (\% on } \\
\text { stayers) }\end{array}$ & $\begin{array}{l}\text { Destinations outside (\% on } \\
\text { movers) }\end{array}$ & \%movers & \%stayers \\
\hline \multirow[t]{3}{*}{ cluster1 $(N=306)$} & Vanvitelli University (41\%) & $\begin{array}{l}\text { University of Cassino-South. } \\
\text { Lazio }(42 \%)\end{array}$ & $52 \%$ & $48 \%$ \\
\hline & $\begin{array}{l}\text { University of Naples Federico } \\
\text { ॥ (41\%) }\end{array}$ & $\begin{array}{l}\text { University of Rome La Sapienza } \\
(25 \%)\end{array}$ & & \\
\hline & $\begin{array}{l}\text { University of Naples "L'Orientale" } \\
(8 \%)\end{array}$ & $\begin{array}{l}\text { Tor Vergata University of Rome } \\
(5 \%)\end{array}$ & & \\
\hline \multirow[t]{3}{*}{ cluster2 $(N=249)$} & University of Sannio (43\%) & University of Molise (11\%) & $23 \%$ & $77 \%$ \\
\hline & $\begin{array}{l}\text { University of Naples Federico } \\
\text { ॥ (28\%) }\end{array}$ & $\begin{array}{l}\text { Polytechnic University of Turin } \\
(9 \%)\end{array}$ & & \\
\hline & $\begin{array}{l}\text { University of Naples "L'Orientale" } \\
(9 \%)\end{array}$ & $\begin{array}{l}\text { University of Rome La Sapienza } \\
(9 \%)\end{array}$ & & \\
\hline \multirow[t]{3}{*}{ cluster3 $(N=196)$} & University of Salerno (71\%) & University of Basilicata (19\%) & $58 \%$ & $42 \%$ \\
\hline & $\begin{array}{l}\text { University of Naples Federico } \\
\text { ॥ (16\%) }\end{array}$ & University of Perugia (8\%) & & \\
\hline & $\begin{array}{l}\text { University of Naples "L'Orientale" } \\
(6 \%)\end{array}$ & University of Siena (7\%) & & \\
\hline \multirow[t]{3}{*}{ cluster4 $(N=629)$} & $\begin{array}{l}\text { University of Naples Federico } \\
\text { ॥ (50\%) }\end{array}$ & $\begin{array}{l}\text { University of Rome La Sapienza } \\
(23 \%)\end{array}$ & $15 \%$ & $85 \%$ \\
\hline & $\begin{array}{l}\text { University of Naples "Parthen- } \\
\text { ope" }(18 \%)\end{array}$ & University of Bologna (11\%) & & \\
\hline & $\begin{array}{l}\text { University of Naples "L'Orientale" } \\
(11 \%)\end{array}$ & Bocconi University (7\%) & & \\
\hline \multirow[t]{3}{*}{ cluster5 $(N=583)$} & University of Salerno (70\%) & University of Basilicata (11\%) & $35 \%$ & $65 \%$ \\
\hline & $\begin{array}{l}\text { University of Naples Federico } \\
\text { ॥ (17\%) }\end{array}$ & University of Siena (7\%) & & \\
\hline & $\begin{array}{l}\text { University of Naples "L'Orientale" } \\
(5 \%)\end{array}$ & University of Bologna (7\%) & & \\
\hline \multirow[t]{3}{*}{ cluster6 $(N=856)$} & Vanvitelli University (52\%) & $\begin{array}{l}\text { University of Rome La Sapienza } \\
(35 \%)\end{array}$ & $12 \%$ & $88 \%$ \\
\hline & $\begin{array}{l}\text { University of Naples Federico } \\
\text { ॥ (24\%) }\end{array}$ & $\begin{array}{l}\text { Tor Vergata University of Rome } \\
(18 \%)\end{array}$ & & \\
\hline & $\begin{array}{l}\text { University of Naples "L'Orientale" } \\
(12 \%)\end{array}$ & $\begin{array}{l}\text { University of Cassino-South. } \\
\text { Lazio (8\%) }\end{array}$ & & \\
\hline \multirow[t]{3}{*}{ cluster7 $(N=1330)$} & University of Salerno (65\%) & $\begin{array}{l}\text { University of Rome La Sapienza } \\
(37 \%)\end{array}$ & $12 \%$ & $88 \%$ \\
\hline & $\begin{array}{l}\text { University of Naples Federico } \\
\text { ॥ (18\%) }\end{array}$ & University of Bologna (7\%) & & \\
\hline & $\begin{array}{l}\text { University of Naples "L'Orientale" } \\
(5 \%)\end{array}$ & Bocconi University (5\%) & & \\
\hline
\end{tabular}

\section{Acknowledgements}

This study was supported by the Ministero dell'Università e della Ricerca, Italy. PRIN 2017. From high school to job placement: Micro-data life course analysis of university student mobility and its impact on the Italian North-South divide, $\mathrm{n}$. 14 2017HBTK5P- CUP B78D19000180001.

\section{Authors' contributions}

FS is responsible for data preparation and data analyses. MPV is responsible for the introduction and the literature review. GR conceived the study, participated in its design and coordination, and helped to draft the manuscript. All the authors equally commented analyses results, read and approved the final version of the manuscript.

Funding

Italian Ministerial grant PRIN 2017 CUP: B78D19000180001. Recipient: Giancarlo Ragozini. 


\section{Availability of data and materials}

The micro-data at student level used for the analyses are available by the ANS archive only for the universities involved in the Italian Ministerial grant PRIN 2017 CUP: B78D19000180001. The data analyzed are derived from the MOBYSU.IT database.

\section{Declarations}

Competing interests

The authors declare that they have no competing interests.

\section{Author details}

${ }^{1}$ Department of Political Science, University of Naples Federico II, via Rodinó 22A, 80138 Naples, Italy. ${ }^{2}$ Department of Political and Social Studies, University of Salerno, Via Giovanni Paolo II 132, 84084 Fisciano, Italy.

Received: 29 December 2020 Accepted: 19 October 2021

Published online: 31 January 2022

\section{References}

Bacci, S., \& Bertaccini, B. (2020). Assessment of the university reputation through the analysis of the student mobility. Social Indicators Research.

Bates, D., Mächler, M., Bolker, B., \& Walker, S. (2015). Fitting linear mixed-effects models using Ime4. Journal of Statistical Software, 67(1), 1-48. https://doi.org/10.18637/jss.v067.i01.

Browne, W. J., \& Rasbash, J. (2009). MCMC Estimation in MLwiN. Centre of Multilevel Modelling: University of Bristol

Ciriaci, D. (2014). Does university quality influence the interregional mobility of students and graduates? The case of Italy. Regional Studies, 48(10), 1592-1608.

Columbu, S., Porcu, M., Primerano, I., Sulis, I., \& Vitale, M. P. (2020). Geography of Italian student mobility: a network analysis approach. Socio-Economic Planning Sciences, 100918

Columbu, S., Porcu, M., \& Sulis, I. (2020). University choice and the attractiveness of the study area: Insights on the differences amongst degree programmes in Italy based on generalised mixed-effect models. Socio-Economic Planning Sciences, 100926

D'Agostino, A., Ghellini, G., \& Longobardi, S. (2019). Out-migration of university enrolment: the mobility behaviour of Italian students. International Journal of Manpower, 40(1), 56-72.

Dotti, N. F., Fratesi, U., Lenzi, C., \& Percoco, M. (2013). Local labour markets and the interregional mobility of Italian university students. Spatial Economic Analysis, 8(4), 443-468.

Enea, M. (2018). From South to North? Mobility of southern Italian students at the transition from the first to the second level university degree. In C. Perna, M. Pratesi, \& A. Ruiz-Gazen (Eds.), Studies in theoretical and applied statistics (pp. 239-249). Springer.

Fernex, A., de Vries, E., \& Lima, L. (2017). Articulating perspectives on international and social mobility in higher education. European Journal of Higher Education, 7(1), 3-14.

Genova, V. G., Tumminello, M., Enea, M., Aiello, F., \& Attanasio, M. (2019). Student mobility in higher education: sicilian outflow network and chain migrations. Electronic Journal of Applied Statistical Analysis, 12(4), 774-800.

Giambona, F., Porcu, M., \& Sulis, I. (2017). Students mobility: assessing the determinants of attractiveness across competing territorial areas. Social Indicators Research, 133(3), 1105-1132.

Goldstein, H. (2005). Multilevel Models. Wiley.

Impicciatore, R., \& Panichella, N. (2019). Internal migration trajectories, occupational achievement and social mobility in contemporary Italy. A life course perspective. Population, Space and Place, 25(6), e2240.

Impicciatore, R., \& Tosi, F. (2019). Student mobility in Italy: the increasing role of family background during the expansion of higher education supply. Research in Social Stratification and Mobility, 62, 100409.

Lombardi, G., \& Ghellini, G. (2019). The effect of grading policies on Italian Universities attractiveness: a conditional multinomial logit approach. Electronic Journal of Applied Statistical Analysis, 12(4), 801-825.

MOBYSU, IT. (2016). Database MOBYSU.IT, Mobilit'a degli studi universitari italiani, Protocollo di ricerca MIUR-Universit'a degli Studi di Cagliari, Palermo, Siena, Torino, Sassari, Firenze e Napoli Federico II, Fonte dei dati ANS-MIUR/CINECA.

Nifo, A., \& Vecchione, G. (2014). Do institutions play a role in skilled migration? The case of Italy. Regional Studies, 48(10), $1628-1649$.

Pitzalis, M., \& Porcu, M. (2015). Passaggio a Nord. Come si ristruttura il campo universitario Italiano? Scuola Democratica, 6(3), 711-722

Powell, M.J. (2007). Developments of NEWUOA for unconstrained minimization without derivatives. Dept. Appl. Math. Theoretical Phys., Univ. Cambridge, Cambridge, UK, Tech. Rep. DAMTP.

Powell, M.J. (2009). The BOBYQA algorithm for bound constrained optimization without derivatives. Cambridge NA Report NA2009/06, University of Cambridge, 26-46.

Rasbash, J., Charlton, C., Browne, W. J., Healy, M., \& Cameron, B. (2005). Mlwin version 2.02. Centre for Multilevel Modelling, University of Bristol.

Rasbash, J., Steele, F., Browne, W., \& Goldstein, H. (2012). A user's guide to mlwin, v2. 26. Centre for multilevel modelling, University of Bristol.

Restaino, M., Vitale, M.P., \& Primerano, I. (2020). Analysing international student mobility flows in higher education: a comparative study on European countries. Social Indicators Research, 1-19.

Santelli, F., Scolorato, C., \& Ragozini, G. (2019). On the determinants of student mobility in an interregional perspective: a focus on Campania region. Italian Journal of Applied Statistics, 31(1), 119-142. 
Santelli, F., Scolorato, C., \& Ragozini, G. (forthcoming). Alcune considerazioni sulla mobilità degli studenti universitari campani. FrancoAngeli.

Snijders, T. A., \& Bosker, R. J. (2011). Multilevel analysis: an introduction to basic and advanced multilevel modeling. Sage. Van Duijn, M. A., Van Busschbach, J. T., \& Snijders, T. A. (1999). Multilevel analysis of personal networks as dependent variables. Social Networks, 21(2), 187-210.

\section{Publisher's Note}

Springer Nature remains neutral with regard to jurisdictional claims in published maps and institutional affiliations.

Submit your manuscript to a SpringerOpen ${ }^{\circ}$ journal and benefit from:

- Convenient online submission

- Rigorous peer review

- Open access: articles freely available online

- High visibility within the field

- Retaining the copyright to your article

Submit your next manuscript at $\mathbf{s p r i n g e r o p e n . c o m ~}$ 